\title{
Seleção e Formação do Pessoal das Entidades Fiscalizadoras Superiores
}

\author{
FREITAS CAVALCANTI \\ Ministro do Tribunal de Contas da União \\ (Trabalho elaborado para o VII Congresso \\ Internacional das Instituições Superiores \\ de Contrôle das Finanças Públicas - Montreal, setembro, 1971.)
}

1. INFORME PRELIMINAR

A fiscalização financeira e orçamentária é exercida, conforme preceitua a Constituição, pelo Congresso Nacional, mediante contrôle externo, com o auxílio do Tribunal de Contas da União, e pelos sistemas de contrôle interno, cometido aos órgãos setoriais de administração financeira, contabilidade e auditoria.

Tem assim o Tribunal de Contas competência específica originàriamente vinculada à cooperação com o Poder Legislativo na relevante tarefa que lhe cumpre executar e abrange sob sua jurisdição as unidades administrativas dos três Podêres da União, as autarquias, as emprêsas públicas, as fundações mantidas pelo Estado e demais órgãos postos por determinação legal em idêntico regime de fiscalização.

De sua parte, cumpre o Congresso Nacional a alta missão político-constitucional ao proceder anualmente ao julgamento das contas do Presidente da República, devidamente formalizadas através dos balanços gerais da União e do relatório da Inspetoria de Finanças do Ministério da Fazenda sôbre a execução do orçamento e a situação da administração financeira federal. São elas remetidas ao Congresso com o parecer conclusivo do Tribunal de Contas aprovado em sessão especial, na presença de autoridades e técnicos, compreendendo a análise dos balanços orçamentário, financeiro e patrimonial e a apreciação dos temas mais importantes da ação governamental.

No atual sistema de fiscalização das finanças públicas, de caráter descentralizado, à base de métodos usuais de auditoria, 
exercido através do exame de demonstrativos contábeis, certificados técnicos e atos de aprovação da autoridade administrativa, poderá o Tribunal de Contas, a qualquer tempo, requisitar a documentação primária da despesa arquivada nas repartições competentes e realizar inspeções in loco, para cujo êxito deve propiciar o Poder Público as condições indispensáveis.

Pretendeu-se, dêsse modo, adotar uma estrutura de fiscalização que, ao preservar a autonomia, a eficiência e a autoridade do órgão superior de contrôle no que é considerado essencial ao desempenho de suas funções constitucionais, não afetasse a dinâmica das atividades do Estado por meio de formalidades e virtuosismos prejudiciais à marcha dos negócios públicos.

Dir-se-ia que o Estado brasileiro buscou um tipo de físcalização compatível com o seu estágio de desenvolvimento econômico, sem prejuízo dos objetivos básicos do contrôle.

Foi o que se verificou com a derrogação do sistema anterior nascido com a República em fins do século passado, teòricamente sob a inspiração da Lei italiana de 14 de agôsto de 1864 , baseado no exame prévio da despesa, sua legalidade, classificação orçamentária, imputação a crédito próprio, formando um processo de centralização por parte do órgão fiscalizador, a começar pelo registro e distribuição dos créditos, o que levaria a supor que uma das chaves do Tesouro Nacional estivesse sob a guarda do Tribunal de Contas.

O nôvo regime surgiu, assim, não apenas e pròpriamente da exigência de aperfeiçoamento inerente à doutrina e forma de fiscalização, mas também da superior e irreprimível conveniência de se armar o Estado de mecanismo mais flexivel para a execução da obra de govêrno no atual lance do desenvolvimento nacional.

Cumpre mencionar os seguintes conclaves levados a efeito em Brasilia, a partir de 1968, por iniciativa do Tribunal de Contas da União, ou com a sua participação, tendo em vista a implantação e adequado funcionamento do sistema de contrôle das finanças públicas estabelecido na Constituição de 24 de janeiro de 1967:

I - Encontros Nacionais (2) de Diretores e Delegados do T.C.U. nos Estados, com temário prèviamente fixado;

II - reuniões (4) do Tribunal com os dirigentes dos órgãos de contrôle interno do Poder Executivo - Inspetores-Gerais de 
Finanças dos Ministérios - visando ao ajustamento dos sistemas de contrôle interno e externo;

III - 6? Congresso dos Tribunais de Contas do Brasil, sob os auspícios do T.C.U., em novembro de 1970 , com a presença de delegações de todos os Estados da Federação e observador internacional do Banco Interamericano do Desenvolvimento; e

IV - reuniões conjuntas (2) em maio de 1971 dos membros do Tribunal de Contas da União com a Comisão de Fiscalização Financeira da Câmara dos Deputados.

Por outro lado, vem a Côrte de Contas participando ativamente de simpósios regionais, realizados por iniciativa de Prefeitos e outras autoridades administrativas para exame conjunto das resoluções e normas que regulam a aplicação dos recursos federais transferidos aos Estados e Municípios e os respectivos processos de comprovação de despesas.

Com os Tribunais de Contas dos Estados e do Distrito Federal mantém o T.C.U. entendimentos de alto nível com vistas à formulação de um sistema uniforme de contrôle dos recursos financeiros destinados aos planos nacionais de desenvolvimento econômico e social.

\section{RECRUTAMENTO E SELEÇÃO}

Pela natureza especifica de suas atribuições constitucionais, dispõe o Tribunal de Contas da União de quadro próprio de pessoal, além de competência privativa para provimento dos cargos mediante concurso público de provas ou de provas e títulos, observados os princípios gerais inscritos na Constituição e nas leis para admissão de pessoal ao serviço civil da União.

Detém, assim, a instituição de contrôle das finanças do Estado a mesma prerrogativa dos Tribunais Superiores do Poder Judiciário constante de norma consagrada no Direito Positivo brasileiro, podendo propor ao Legislativo a criação ou a extinção de cargos e a fixação dos respectivos vencimentos, atendido o critério da paridade de remuneração fixado para os servidores dos três Podêres da União titulares de cargos de atribuições iguais ou assemelhadas, nos têrmos da reforma constitucional promulgada a 17 de outubro de 1969 e da Lei Complementar de 6 de maio de 1971.

A seleção por concurso de provas incorporou às atividades do Tribunal numeroso grupo de funcionários especializados; num total de 567 servidores, afora o pessoal dos serviços auxiliares sujeito a regime jurídico especial, $20 \%$ são portadores de diplo- 
ma universitário de nível superior e $1,5 \%$ de outros cursos técnicos.

Para o recrutamento e a seleção do seu pessoal pôde o Tribunal de Contas da União obter a cooperação do Departamento Administrativo do Pessoal Civil (DASP), que é o órgão central do sistema de pessoal, responsável pelo estudo, formulação de diretrizes, orientação, coordenação, supervisão e contrôle dos assuntos concernentes à administração do pessoal civil da União.

Releva notar que o êxito do sistema de auditoria financeira e orçamentária, de caráter descentralizado - em País de grande extensão territorial, com 22 Estados e cêrca de 4.000 Municípios, em fase de desenvolvimento marcada por grandes projetos nacionais * - está a depender do refôrço de pessoal de alto nível técnico, em número suficiente, e da utilização do processo de computação automática, para acionar a autoridade e a mecânica do contrôle e captar os resultados da ação governamental.

Com as medidas complementares, ora em estudo, pretendese manter um esquema flexível e permanente de inspeções em todo o País, abrangendo os principais setores da atividade do Estado, na Administração Direta e na Indireta, de modo a aferir a eficácia do mecanismo do contrôle interno, especialmente no que se relaciona com os contratos de obras, regime de licitação e fiscalização, as apropriações de material e o funcionamento dos almoxarifados.

Merece, por igual, atenção especial a fiscalização dos recursos financeiros transferidos pela União aos Estados, Territórios e Municípios, à conta dos Fundos de Participação, de origem constitucional, formados por percentuais dos Impostos sôbre a Renda e sôbre os Produtos Industrializados, cuja aplicação é disciplinada, de acôrdo com os programas gerais de desenvolvimento, em setores prioritários de educação, saúde e saneamento básico.

Daí o empenho com que a insígne Presidência, exercida pelo Ministro Abgar Renault, fiel à orientação do Plenário, se ocupa firmemente da reorganização do quadro de pessoal, em bases realistas, para adaptá-lo às novas técnicas de serviço,

* V.g. Programa de Integração Nacional, com a construção da Transamazônica e obras de colonização para a ocupação econômica de 2 milhōes de $\mathrm{km}^{2}$ da Amazônia, Sistema Básico Nacional de Telecomunicações, expansão do Plano da Siderurgia Nacional e da indústria de construção naval. 
com a criação da série de classes de Técnico de Contrôle Externo, constituídas de especialistas em Contabilidade, Administração Pública, Economia, Direito Administrativo e Direito Financeiro, além de admissão por contrato de engenheiros de operação e mestres-de-obras para fiscalização específica.

Neste sentido estão sendo completados os estudos da elaboração de anteprojeto de lei com adequada justificação, a ser encaminhado à consideração do Congresso Nacional.

\section{FORMAÇÃO PROFISSIONAL}

O processo de formação profissional, básico no sistema de contrôle, está associado ao próprio espírito da reforma por que passa a instituição, com a radical alteração nos métodos de trabalho, superadas as rotinas e práticas anteriores, para o desempenho das novas funções.

Desde 1968, com a criação do Centro de Aperfeiçoamento de Servidores, diretamente subordinado à Presidência, vem o Tribunal exercitando o pessoal nos misteres de auditoria financeira e orçamentária, através de cursos regulares, extraordinários e avulsos e demais instrumentos de motivação profissional e cultural.

Os cursos regulares são destinados à preparação e aperfeiçoamento sistemático, mediante a aprendizagem das disciplinas relacionadas com as atividades do Tribunal, para a formação de técnicos em Auditoria Financeira e Orçamentária, a habilitação de pessoal em funções de chefia e direção e o acesso dos integrantes de carreira auxiliar à carreira principal da mesma correlação profissional. Os cursos extraordinários têm finalidades especiais com vistas à adaptação ou readaptação de servidores e o treinamento em caráter intensivo de pessoal dos órgãos regionais, além do preparo de instruções de emergência para determinadas inspeções. Compreendem os cursos avulsos o ensino de disciplina isolada de Cultura Humanística ou de especialidade técnica julgada de interêsse do Tribunal.

Os planos de treinamento, matérias, condições de matrícula, regime didático e disciplinar e outras normas para administração dos cursos são fixados pela Presidência.

Incumbe ainda ao Centro de Aperfeiçoamento de Servidores promover o intercâmbio com outras instituições visando ao aperfeiçoamento do pessoal no País ou no estrangeiro, mediante bôlsas de estudo. 
Em regra, os cursos são ministrados por diretores e técnicos de alto nível do próprio Tribunal, alguns dêles com experiência da cátedra universitária, podendo ser autorizado contrato com especialistas de renome para cursos intensivos sôbre temas fundamentais da problemática do contrôle brasileiro.

Eis os cursos já realizados com vistas ao preparo e aperfeiçoamento do pessoal:

1. Prática de Auditoria Financeira e Orçamentária, desdobrado em dois subperíodos com duração de 1 ano;

2. Iniciação às Funções de Controlador de Contas Públicas, com duração de 1 ano;

3. Curso Extraordinário Sôbre o Fundo de Participação dos Municípios, com duração de 6 meses; e

4. Curso Especial de Auditoria Contábil, de caráter intensivo, em regime de tempo integral, ministrado por equipe pertencente a firma internacional de auditoria em convênio com o T.C.U.

No corrente ano o programa do CAS inclui, como atividades principais, o 2․ Curso Extraordinário sôbre o Fundo de Participação dos Municípios e o Curso Extraordinário sôbre Contrôle Externo.

Cumpre, de outro passo, considerar no processo de aprimoramento profissional, além da participação nos seminários internacionais, a conveniência da aprovação de projeto sôbre intercâmbio de funcionários especializados, em regime de estágio regular, o qual seria objeto de convenção ou acôrdo entre as entidades fiscalizadoras superiores, para a avaliação e o confronto das técnicas operacionais de contrôle, tendo em vista a evolução do sistema peculiar a cada país.

O Tribunal de Contas da União aprovou êste ano a indicação de servidores para (1) representá-lo no Seminário InterRegional sôbre Auditoria Governamental, promovido pela Organização das Nações Unidas e pela International Organization of Supreme Audit Institutions, em Baden, na Áustria, de 3 a 14 de maio de 1971; (2) participar do 20 ? Simpósio Nacional da Associação dos Contadores do Govêrno Federal, em Washington, DC, de 28 a 30 de junho de 1971; e (3) freqüentar, em regime de bôlsa de estudo, no período de seis meses, curso de extensão cultural de Direito Administrativo no Instituto de Alta Cultura de Lisboa. 
Subject 1

\section{AUDIT STAFF PERSONNEL SELECTION AND TRAINING}

PRELIMINARY REMARKS

As stated in the Constitution, the financial and budgetary control is carried out, by the National Congress, through an external control, with the assistance of the Federal Court of Audit, and by the internal control systems, ascribed to the sectorial offices of financial administration, accounting and audit.

Thus, the specific capacity of the Court of Audit is originally linked to the cooperation with the Legislative Power in the important task incumbent upon the latter. It has jurisdiction over the administrative agencies of the three branches of government, as well as "authorities", public enterprises, foundations supported by the State and other institutions legally under the same control regime.

The National Congress accomplishes, in its turn, the high political-constitutional task, which consists in annually performing the judgement of the accounts of the President of the Republic, duly formalized in the over-all balance sheets of the Government and in the report of the Finance Inspectorate of the Finance Ministry concerning the execution of the budget and the situation of the federal financial administration. These documents are sent to the National Congress together with the conclusive opinion of the Court of Audit, approved in a special session attended by authorities and experts, covering the analysis of the budgetary, financial and patrimonial balance sheets and the evaluation of the most important topics of the governmental action.

In the present system of public finance control, of a decentralized nature, based on the usual audit methods and carried out through the examination of accounting statements, technical certificates and opinions issued by the administrative authorities, the Court of Audit can, at any time, requisition primary expanditure documents filed in the agencies, as well as perform in loco inspections, for the success of which the Government must provide the indispensable conditions.

Through such a policy, the aim was to adopt a control structure able to preserve the autonomy the efficiency and the authority of the supreme audit institution, in the aspects considered essential to the fulfillment of its constitutional functions, without affecting the performance of the State's activities by means of formalities and technicalities harmful to the governmental management process.

It could be said that the Brazilian State sought a type of control compatible with its stage of economic development, without jeopardizing the basic purposes of control.

This ocurred with the derogation of the former system born with the Republic at the end of the past century, theoretically under the inspiration of the Italian Law of August 14, 1864. Such system was based on the previous examination of the expenditures and their legality, as well as budgetary classification and proper credit imputation, thus generating a process of centralization at the audit institution, beginning with the registration and distribution of the credits, which would lead to the impression that one of the keys to the National Treasury was kept by the Court of Audit. 
Thus, the new regime emerged not only from the need of improvement inherent to the doctrine and to the type of control being performed, but also from the superior and unrestrainable convenience of furnishing the State with a more elastic mechanism to accomplish the government's task at the present stage of the national development.

From 1968 on the following meetings were held in Brasilia, either sponsored by the Court of Audit of Brazil, or with its participation, envisaging the introduction and the adequate perfomance of the system of control of the public finance established in the new Constitution (dated january 24, 1967):

1. 2 National Meetings of Division Heads and State Delegates from the Court, with previously established agendas;

II. 4 meetings held by the Court with the Heads of the internal control offices of the Executive Branch-General Finance Inspectors of the Ministrias-seeking the adjustment of the internal and the external control systems;

III. The 6th Congress of Audit Institutions of Brazil, held in November, 1970, under the sponsorship of T.C.U. (Court of Audit of Brazil), attended by delegations from all the States Courts of Audit and an observer from the Bank for Inter-American Development; and

IV. 2 joint meetings held in May, 1971, by members of the Court of Audit of Brazil with the Financial Control Committee of the Chamber of Deputies.

On the other hand, the Court of Audit has been actively participating in regional symposia, held by mayors and other administrative authorities to jointly study the resolutions and norms regulating the utilization of federal funds transferred to the States and Municipalities, as well as the proper procedures for the control of the respective expenditures.

The Court of Audit of Brazil maintains an interchange of ideas, on a high level, with the Courts of Audit of the States and of the Federal District, aiming at the formulation of a uniform system of control on the funds to be spent on national programs for social and economic development.

\section{RECRUITMENT AND SELECTION}

Due to the specific nature of its constitutional task, the Federal Court of Audit is endowed with a staff of its own and is legally authorized to appoint all its employees, who are recruited and selected through open competitive tests. Such tests may also include a competitive evaluation of professional curricula. All legal and constitutional principles concerning the admission of federal civil personnel must be obeyed.

In this manner, the financial control institution of the State holds the same prerogative as all other Superior Courts of the Judiciary Branch, according to the rule accepted in the Brazilian positive law. It can submit proposals to the Legislature creating or extinguishing posts and determining the respective wages. However, general personnel criteria established for all public servants, with the same or equivalent functions from the three branches, must be observed, in accordance with the constitutional reform promulgated on October 17, 1969, and with the Complementary Law of May 6, 1971.

The selection through open competition brought a large group of specialized officers to the Court's service. Among a total of 567 servants, not including the lower rank personnel hired under a special juridical regime, $20 \%$ have a university degree and $1,5 \%$ are graduated from other technical courses. 
In order to recruit and select its staff, the Court of Audit of Brazil may obtain the cooperation of the Administrative Department for the Civil Personnel (DASP), which is the central organ of the personnel system, responsible for the establishment of policies, guidance, coordination, supervision and study of matters concerning the administration of the civil personnel at the federal level.

It is worth emphasizing that the success of the budgetary and financial audit system, performed on a decentralized basis-in a large country, with 22 States and about 4,000 Municipalities, undergoing a development stage marked by huge national projects * _, depends on the availability of a satisfactory number of additional highly qualified officials and on the use of electronic data processing (EDP), to activate the authority, as well as the process of control, and to collect the results of the governmental action.

With the complementary measures now being studied, a flexible and permanent scheme is intended to be organized to perform inspections throughout the country, covering the fundamental fields of the State's activity, in both diretc and indirect Administration, so that the effectiveness of the internal control mechanism can be evaluated, especially in the area of construction contracts, procurement regime and fiscalization, material appropriaton and the functioning of storehouses.

Special attention must also be given to the control of the funds transferred by the federal Government to the States, Territories and Municipalities, through the participation funds established in the Constitution, which are formed by percentages taken out of the income tax and of the tax on industrialized products. The funds are utilized in priority areas such as education, health and basic sanitation, according to general development programs.

This is the reason for the effort being made by the Court's President, Minister Abgar Renault, following the orientation outlined by the Court's plenary assembly, aiming at the reorganization of the staff, on a realistic basis, in order to adjust it to the new working techniques. One of the outstanding points of such an effort refers to the creation of a career of External Control Expert, to be occupied by specialists in such fields as accounting, public administration, economics, administrative law and public finances. The admission, on a contract basis, of field engineers and master-builders for fiscalization work in their specific fields is also being considered.

For this purpose studies are being conducted to elaborate an adequately justified proposal to be submitted to the Congress.

\section{PROFESSIONAL FORMATION}

Professional formation, which is a basic condition for the effective operation of the control system, is connected with the very spirit of the reform that the institution is now undergoing. It represents a radical change in the working methods, involving the revision of inadequate practices and obsolete routines.

Since 1968, with the creation of the Personnel Training Center, directly subject to the Presidency, the Court has been training its staff in matters concerning budgetary and financial control, through regular, extraordinary and

(*) V.g.: National Integration Program, including the construction of the TransAmazonian Road and the colonization works for the economic occupation of 2 million square kilometers of the Amazon Territory, Basic National Telecommunications System, expansion of the National Steel Plan and of the Shipyard Industry. 
sundry courses, as well as other instruments of professional and cultural enhancement.

Regular courses are dedicated to systematic preparation and specialization, through the study of subjects related to the Court's activites, for the formation of experts in budgetary and financial control, and the preparation of personnel to occupy positions of supervision and direction, as well as for the admission of lower category servants to the main career, within the same professional field. Extraordinary courses are especially aimed at personnel readjustment or readaptation, as well as intensive training of staff from the regional offices, in addition to the administration of emergency briefing for particular inspections. Sundry courses involve the study of isolated subjects on humanistic culture, or of technical specializations considered pertinent to the Court's interests.

Course plans, subjects, enrollment conditions, teachning and disciplinary regimes, as well as other rules necessary to the operation of the courses, are stipulated by the Presidency.

The Personnel Training Center is also required to promote the interchange of employees with other institutions, aiming at personnel specialization in the country or abroad, by means of scholarships.

As a rule, the courses are administered by directors and highly qualified experts selected from the Court's own staff, some of them experienced university professors. Well-known specialists may also be hired for intensive courses dealing with fundamental problems of the Brazilian control complex.

The following are some of the courses already carried through concerning personnel preparation and specialization:

1. Pratice of Budgetary and Financial Audit, divided into two periods, totaling one year;

2. Introduction to the Funtions of the Public Auditor, one year duration;

3. Extraordinary Course on the Participation Fund of the Municipalities, 6 months duration; and

4. Special Course on Accounting Audit, administered, on a full-time intensive basis, by a group of auditors belonging to an international audit firm, according to arrangements made with the Court of Audit.

The program of the PIC for this year includes as major activities the 2nd Extraordinary Course on the Participation Fund of the Municipalities and the Extraordinary Course on External Control.

In reference to the improvement of prefessional standards, besides the participation in international seminars, it is also important to consider the convenience of this Congress passing a resolution concerning the interchange of specialized officers, among our institutions, for a regular briefing period, in order to evaluate and compare techiniques and methods in use in the control systems of each country. Such a measure would help the improvement of our operational standards and could be the object of an agreement among the members of our international organization.

The Federal Court of Audit approved the designation of officers to attend the following promotions abroad, during this year: (1) the Interregional Seminar on Government Auditing, organized by the United Nations and the International of Supreme Audit Institutions (INTOSAI), held in Baden, Austria, from 3 to 14 May, 1971; (2) the 20th Annual National Symposium of the Federal Government Accountants Association, held in Washington, D.C., U.S.A., from 28 to 30 June, 1971; and (3) an extension course on administrative law, on a scholarship basis, at the Institute of High Culture, in Lisbon. 